The International Journal of Engineering and Science (IJES)

|| Volume || 6 || Issue || 5 || Pages || PP 24-31 || 2017 ||

ISSN (e): $2319-1813 \operatorname{ISSN}$ (p): $2319-1805$

THE IJES

\title{
Performance Behaviour of a Spark - Ignition Engine Running on Gasoline - Cadaba farinosa forskk Bioethanol Fuel Mixtures.
}

\author{
Gambo, B.A ${ }^{1}$, Ejilah, I.R ${ }^{2}$. Dahuwa, $\mathrm{K}^{3}$. \\ ${ }^{I}$ Dept of Mechanical/Production Eng., Abubakar Tafawa Balewa University, Bauchi-Nigeria Email: \\ ${ }^{2}$ Dept of Mechanical/Production Eng., Abubakar Tafawa Balewa University, Bauchi-Nigeria. \\ ${ }^{3}$ National Center for Petroleum Research and Development, Abubakar Tafawa Balewa University Bauchi- \\ Nigeria
}

\begin{abstract}
-
In this study, engine performance tests and analysis of blended gasoline ethanol derived from Cadaba farinosa forssk plant at GE2 (98\% gasoline and 2\% ethanol volumetric proportion), GE4, GE6, GE8, and GE10 blended test fuel samples on a TD110-115 single cylinder, four stroke and air-cooled, spark ignition engine test rig, under different loading conditions in line with the SAE practice SAE J1312 June 1995 test protocol. The results show that the specific fuel consumption was better with gasoline than the tested blended fuel samples. In terms of higher engine torque, brake power, brake thermal efficiency, higher BSFC, lower BSEC values, leaner air fuel ratio and comparatively higher exhaust temperature; it was observed that GE2, GE4, and GE6 blended fuel samples exhibited a better performance behavior than gasoline fuel sample under different loading conditions. This could be explained in terms of ; the higher octane number of ethanol, the presence of more unbounded oxygen molecules in the ethanol to support fuel combustion, and the higher calorific value of gasoline and that of the dual fuel mixtures, and better fuel atomization due to the comparatively lower viscosities and densities of the fuel mixtures. For reasons of its satisfactory engine performance behavior, fuel conservation advantages, the candidacy of Cadaba farinosa forssk ethanol and gasoline blends, present the prospects of a potential fuel source and gasoline fuel extender for spark ignition engines.
\end{abstract}

Keywords: Cadaba farinosa forssk, engine performance, ethanol, gasoline, spark ignition engine.

Date of Submission: 01 May 2017

Date of Accepted: 17 May 2017

\section{INTRODUCTION}

The conscious search for better sources of sustainable energy has been on for several years. This is in view of the limited access to petroleum-based fuels, the rising cost of fossil fuel, and the enormous impact of greenhouse gases emission on the environment. In recent years, energy consumption and global carbon intensity have increased significantly, and have caused worldwide concerns over ; the depletion of fossil fuel, scarcity of petroleum products, and, the burning of fossil fuel and anthropogenic activities results in increasing atmospheric $\mathrm{CO}_{2}$ concentration in the atmosphere, and consequently has spurred the search for alternative forms of energy [1].

The world energy demand somewhat increases with the growing number of the world's population and urbanization, and hence, the development of bioenergy as an alternative energy resource would help to reduce these challenges. Different forms of bioenergy can be produced from a wide range of biomass sources, for example, agricultural residues. Biofuel is a promising source of energy because it is generated by the process of photosynthesis, where energy from the sun is captured and transformed into biomass that can be combusted to produce energy at minimal production cost [2]. Liquid biofuel could be processed from plants and agricultural feedstock, such as; sugar cane, and also from forestry wood wastes, and agricultural residues in the form of bioethanol or cellulosic ethanol as renewable fuel. It can also be derived chemically from ethylene or ethane [3]. Ethanol has a simple molecular structure with well- defined physical and chemical properties. Ethanol can be employed as a transportation fuel either in its original form or blended with other fuels, such as; gasoline and diesel fuel respectively. Alcohols, such as, ethanol, are colorless liquids with mild characteristic odors that can be produced by the fermentation of biomass crops, such as; sugarcane, wheat and wood. Using ethanol as fuel for spark ignition (SI) engine has some advantages over gasoline. It is known to demonstrate better anti-knock characteristics and the engine's thermal efficiency improves with increase in compression ratio [4]. However, the oxygen content in ethanol reduces the heating value more than gasoline does [5]. A fuel mixture of 10\% anhydrous ethanol and 90\% gasoline (E10, also referred to in this paper as GE10) sometimes called gasohol, can 
be used in the internal combustion engines without any modification on the engine or fuel system. The E10 blends are known to exhibit an octane numbers (i.e. 2 to 3) higher than regular gasoline, and are approved for use in all new U.S. automobiles for reasons of lower emission advantages, improved engine performance, and reduced dependence on foreign oil to mitigate energy shortages [6]. Other common blends include E5 and E7. These concentrations are generally safe for modern engines running on pure gasoline. As of 2006, mandates for blending bioethanol to vehicle fuels had been enacted in at least 36 states/provinces and 17 countries at the national level, with most mandates requiring a blend of 10 to $15 \%$ ethanol with gasoline [7].

Over the years, researchers have improved on how to extract ethanol in commercial quantity from non-edible agricultural products [8]. Novel and promising technology that uses enzymes to break down cellulose and release the plants sugar for fermentation into ethanol are being developed and taken into account [9]. In this paper, bioethanol processed from Cadaba farinosa forssk plant is of interest. The plant is a slender shrub with strongly furrowed stem predominantly found in the sahelian region of Northern Nigeria. The fruit is oblong and cylindrically- shaped with contractions of $5 \mathrm{~cm}$ long and densely farinose. The interior of the fruit is orange-red when mature. The seeds are the size of a millet grain, comma-shaped, shiny, dark brown, and arranged in a single layer within the fruit [10]. This research paper will report the findings of the engine performance behavior of unleaded gasoline fuel samples blended with bioethanol derived from Cadaba farinosa forssk plant, and the result evaluated in terms of; engine torque, brake power, brake specific fuel consumption (BSFC), brake thermal efficiency (BTE), brake specific energy consumption(BSEC) purposed to identify the candidacy and potentials of Cadaba farinosa forssk derived ethanol as a gasoline fuel extender in spark ignition engines.

\section{II.MATERIALS AND METHOD}

2.1 Ethanol production from Cadaba farinosa forssk plant.

The production of ethanol was carried out by firstly, collecting Cadaba farinosa forssk shrubs from Bayara Market, in the southern out sketch of Bauchi metropolis, Nigeria, .the stem of the shrub was crushed into smaller particle sizes to make it more amenable for cellulose hydrolysis. The resulting sucrose in the plant was then converted into glucose by saccharification, before converting the glucose to ethanol through yeast fermentation. The filtrate of the sample was then distilled by heating it to a temperature of $80^{\circ} \mathrm{C}$ in a fractional distillation apparatus and kept so for eight (8) hours. The alcohol evaporated during this period was condensed in a receiver to produce roughly $95 \%$ ethanol [11].

\subsection{Determination of fuel properties of ethanol and gasoline, and fuel blends.}

The physical properties of gasoline, and Cadaba farinosa forssk ethanol blended samples was determined in accordance with standardized ASTM test protocols, and these include; ASTM D97-93, ASTM D2015-85, ASTM D 93-94, ASTM D2885, ASTM D 445, ASTM D 7689-11, ASTM D7346-15, ASTM D4809-13 for density, calorific value, flash point, octane number, kinematic viscosity, cloud point, pour point, and heat of combustion respectively [12].

\subsection{Engine performance test.}

A TD 110-TD 115 single cylinder four stroke spark ignition engine test bed, and incorporated with a hydraulic dynamometer (refer to Tables 1 specifications, and the schematic diagram of the test rig in Fig. 1 respectively) was used to conduct the engine performance analysis. The engine performance experiments of the gasoline fuel sample (GF) and Cadaba farinosa forssk blended gasoline fuel samples; GE2 (i.e. 2\% ethanol and 98\% gasoline by volumetric proportion), GE4, GE6, GE8 and GE10 were conducted in accordance with standardized SAE practice SAE J1312 procedure for four stroke compression and spark ignition engines [13]. The time taken by the engine to consume $8 \mathrm{ml}$ of the fuel was recorded, the engine was test ran at the speed of $1500 \mathrm{rpm}$, and at an incremental load of $500 \mathrm{~g}$, within the load range of 500-3000g, Benchmark tests of engine performance on gasoline were at the onset of the performance experimentation conducted for the purpose of comparison, with the performance of ethanol blended fuel samples. The torque, exhaust temperature, barometric pressure readings of the engine running on all fuel samples was also recorded.The percentage of blends, and load, were varied and their corresponding engine performance characteristics, such as; torque, brake power mass fuel flow rate, air fuel ration, percentage heat loss and exhaust temperature, BSFC, BSEC, and BTE were measured and calculated where necessary.

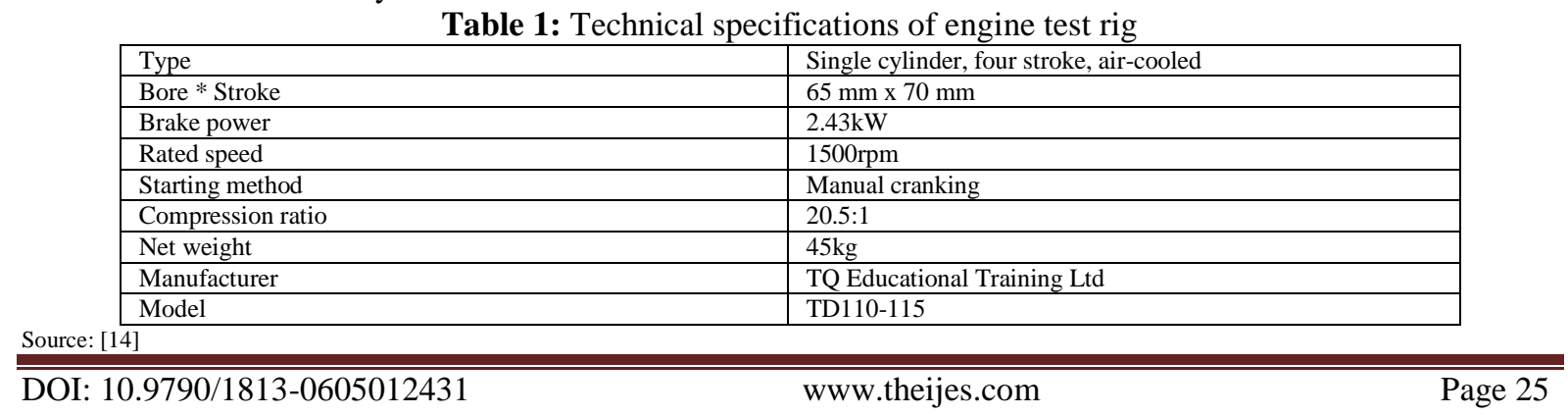




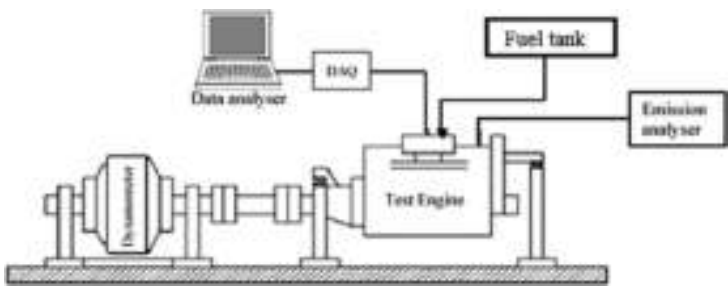

Figure 1. Schematic diagram of engine test rig [15]

\section{RESULTS AND DISCUSSION.}

\subsection{Fuel property of gasoline, ethanol and blended fuel samples}

The results of fuel properties characteristics of fuel samples produced from Cadaba farinosa forskk ethanol are presented in Table 2. It could be seen from Table 2 that the density and specific gravity (6.62\%), kinematic viscosity, pour point $(63.67 \%)$, cloud point $(66.67 \%)$, and octane number $(12.66 \%)$ of gasoline are comparatively lower than that of ethanol extracted from Cadaba farinosa forskk shrub. Conversely, the flash point (56.98\%), calorific value (59.66\%), and heat of combustion (47.44\%) values of gasoline are higher than their ethanol counterpart. It could also be observed that the density, specific gravity, kinematic viscosities, flash point, pour point, cloud points, octane number of blended fuel samples (i.e. GE2,GE4,GE6,GE8 and GE10), somewhat increases with the increase in volumetric proportion Cadaba farinosa forskk ethanol in the fuel samples. While, the calorific value and heat of combustion of blended fuel samples decrease with increase in volumetric concentration of ethanol in the blended fuel samples.

Furthermore, it has been revealed that, blending ethanol with gasoline has multiple effects. Ethanol is known to increases the heat output of the unleaded gasoline. It should also be noted that the higher the concentrations of ethanol, the more the tendency of fuel samples develop polar solvent-type characteristics with corresponding effects on fire suppression operations. Hence, at higher ethanol concentrations, the more it manifests its hydrophilic tendency. Furthermore, because ethanol and gasoline posses similar specific gravities (refer to Table 2), the fuels mixture could be readily achieved with minimal agitation, with their blends exhibiting the characteristic of a typical suspension than a true solution. This makes the challenges of phase separation possible in fuel storage systems where water is present [16]. To rid this challenge, two distinctive emulsification techniques for water and oil; water- in-oil (W/O) and oil- in-water (O/W) are usually employed [17]. However, two-phase water- in-oil (W/O) technique is usually preferred for internal combustion engines compared to oilin-water $(\mathrm{O} / \mathrm{W})$ technique [18]. In this case, the fuel mixtures were blended in a mechanical homogenizing stirring machine at a speed of $800 \mathrm{rpm}$ for $15 \mathrm{~min}$ to achieve phase stabilization. It has also been established that when the rotational speed increases (i.e. within the range of $300 \mathrm{rpm}$ to $1400 \mathrm{rpm}$ ), stabilization increases as well [19].

\subsection{Effect of fuel samples on engine torque and brake power.}

The relationship between the torque and brake power and engine load for the fuel sample understudy is shown in Figs. 2.and 3. It could be seen that the brake power peaks at engine load of 2000 for tested fuel samples, and declines relatively in value for blended fuel samples due to marginally higher viscosity and lower heating value on account of the higher concentration of ethanol in the blended fuel samples [20]. Hence, this explains why the brake power of GE8 $(1.661 \mathrm{~kW})$ and GE10 $(1.654 \mathrm{~kW})$ blends exhibit lower brake power than gasoline fuel $(1.663 \mathrm{~kW})$; and GE2 $(1.671 \mathrm{~kW})$, GE4 $(1.668 \mathrm{~kW})$, and GE6 $(1.665 \mathrm{~kW})$ fuel demonstrated higher brake power that gasoline fuel respectively. The higher torque and brake power values of GE2, GE4 and GE6 fuel blends at the peak load could be attributed to the combined effects of the increased fuel consumption that goes with increase in engine load [20],

Table 2. : Fuel properties of gasoline, ethanol and blended fuel samples.

\begin{tabular}{|l|l|l|l|l|l|l|l|}
\hline Fuel Property & Gasoline & Ethanol & GE 2 & GE 4 & GE 6 & GE 8 & GE 10 \\
\hline Density at $20^{\circ} \mathrm{C}\left(\mathrm{kg} / \mathrm{m}^{3}\right)$ & 740 & 789 & 739 & 749 & 754 & 757 & 761 \\
\hline Specific gravity & 0.740 & 0.789 & 0.739 & 0.749 & 0.754 & 0.757 & 0.761 \\
\hline Kinematic viscosity $@ 40^{\circ} \mathrm{C}\left(\mathrm{mm}^{2} / \mathrm{s}\right)$ & 4.875 & $?$ & 5.025 & 5.116 & 5.250 & 5.380 & 5.516 \\
\hline Flash point $\left({ }^{\circ} \mathrm{C}\right)$ & 26.5 & 11.4 & 28.0 & 29.0 & 29.8 & 30.5 & 31.3 \\
\hline Pour point $\left({ }^{\circ} \mathrm{C}\right)$ & -22 & -8 & -17 & -15 & -14 & -12 & -9 \\
\hline Cloud point $\left({ }^{\circ} \mathrm{C}\right)$ & -18 & -6 & -13 & -12 & -11 & -9 & -7 \\
\hline Octane number & 93.2 & 105 & 95.1 & 97.0 & 98.6 & 100.2 & 102.3 \\
\hline Calorific value $(\mathrm{MJ} / \mathrm{kg})$ & 47.1 & 29.5 & 46.1 & 45.2 & 44.5 & 44.1 & 43.5 \\
\hline Heat of combustion $(\mathrm{MJ} / \mathrm{kg})$ & 34.84 & 23.63 & 33.28 & 32.87 & 32.25 & 31.85 & 30.70 \\
\hline
\end{tabular}

Source: [21] 
Higher octane number of ethanol and calorific value of gasoline in the blended mixture (refer to Table 2). According to Agarwal [22], the octane number of the fuel samples is raised with the addition of ethanol to the gasoline fuel, and this consequently enhances the manifestation of antiknock behavior that allows for more advanced timing, higher combustion pressure, and higher engine output torque and power respectively. In the case of dual fuel mixtures with higher proportions of ethanol, less torque is produced due to the lower energy released on account of the low calorific value of the ethanol.

\subsection{Effect of fuel samples on brake specific fuel consumption.}

Figure 4, shows the variation of brake specific fuel consumption (BSFC) of gasoline and for various blends of ethanol and gasoline fuel at different loads. It could be seen that the BSFC decreases with brake load; and with GE2 (269.42 g/kW-h), GE4 (272.95 g/kW-h), GE6 (275.44 g/kW-h), GE8 (283.44 g/kW-h), and GE10 (292.20 g/kW-h) fuel samples exhibiting higher BSFC level than gasoline $(271.66 \mathrm{~g} / \mathrm{kW}-\mathrm{h})$ at the engine load of $2500 \mathrm{~g}$. The increase of the engines brake power with load could be partly responsible for the decreases in the engine BSFC for all tested fuel samples (Bhattacharya, et al., 2006). It is of importance to note that BSFC's are calculated on weight basis, therefore fuel samples with higher densities are likely to exhibit higher BSFC values [23], and this in turn explains why the ethanol blended fuel samples (GE2, GE4, GE6, GE8, and GE10), with their relatively higher densities and viscosities (refer to table 2), are predisposed to higher BSFC behavior, with less economic benefits in terms of fuel consumption. According to Masjuki and Maleque [24], three factors could be advanced for the appreciably higher specific fuel consumption for tested fuel samples, and these include; higher densities (specific gravity), higher viscosity and lower heating values of the blended fuel samples. Furthermore, since BSFC is a measure of the efficiency of the engine in using the fuel supplied to produce work,

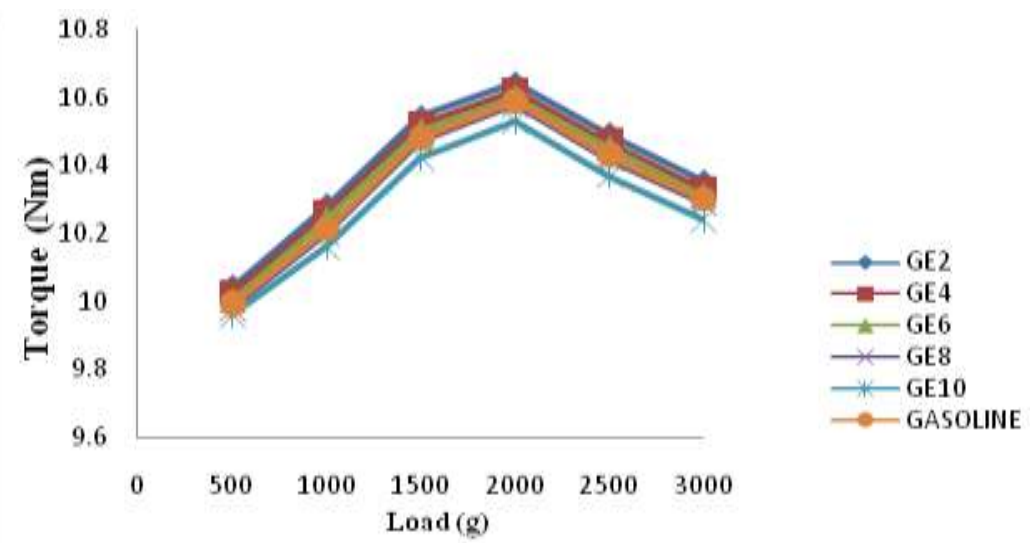

Figure 2. Variation of torque versus engine load for tested fuel samples

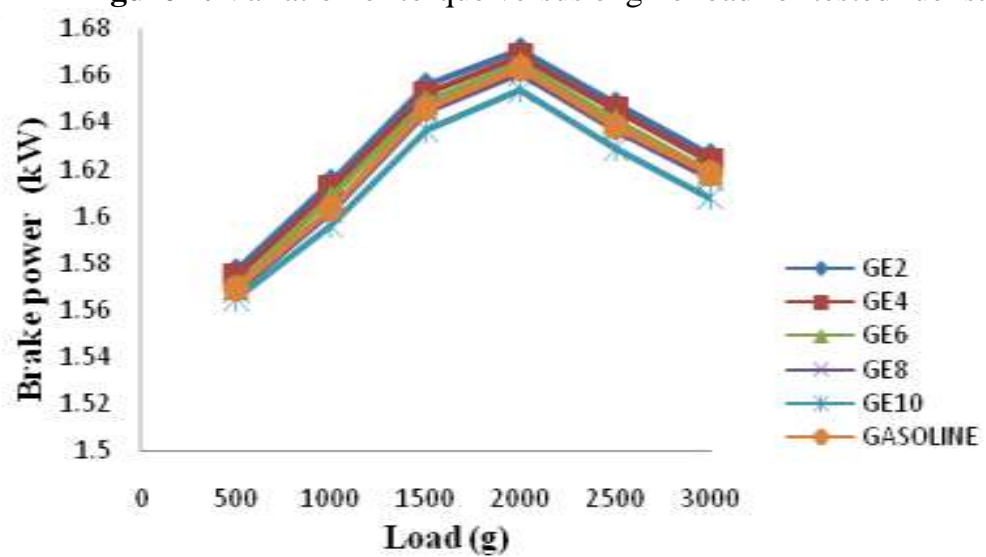

Figure 3. Variation of brake power versus engine loads for tested fuel samples. 


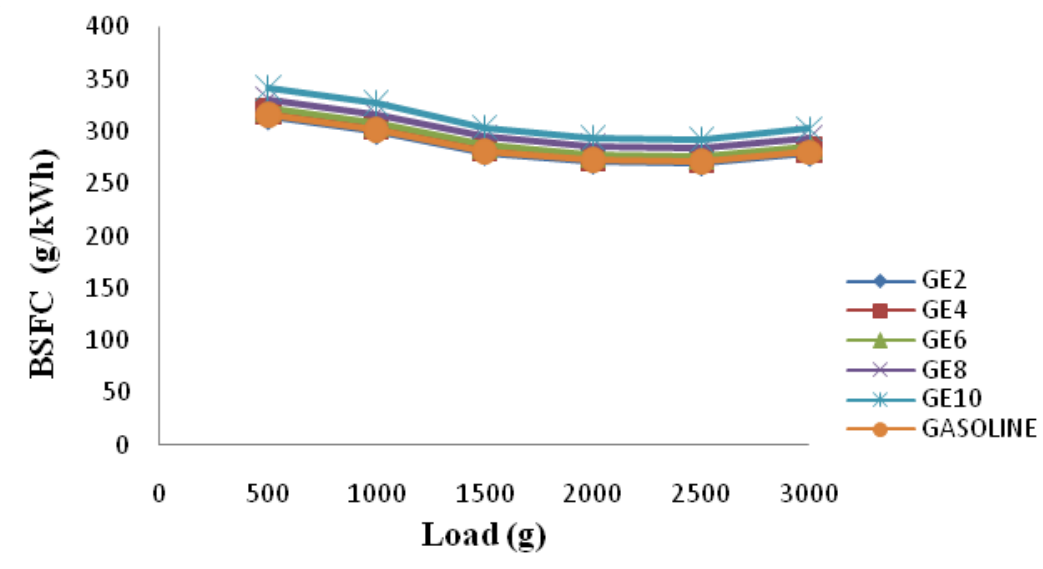

Figure 4. Variation of BSFC versus engine loads for tested fuel samples.

It is desirable to obtain a lower value of BSFC meaning that the engine used less fuel to produce the same amount of work. Hence BSFC values provide a clue on the fuel economy characteristics of fuel samples under investigation.

\subsection{Effect of fuel samples on brake thermal efficiency.}

Brake thermal efficiency (BTE) present an idea of the output generated by the engine with respect to heat supplied in the form of fuel. The variation of brake thermal efficiency with load is shown in Fig. 5. For all fuel samples, the brake thermal efficiency increases with increase in load. This trend can be attributed to the rise in power with increase in engine load. The initial increase in BTE could also be explained in terms of the improved combustion of fuel, and reaches a peak at a load of $2500 \mathrm{~g}$ and slopes slightly downward at the maximum load of $3000 \mathrm{~g}$. At the critical engine load of $2500 \mathrm{~g}$, it could be observed that the brake thermal efficiency of GE2 $(0.289 \%)$. GE4 $(0.292 \%)$, GE6 $(0.294 \%)$, GE8 $(0.288 \%)$ and GE10 $(0.283 \%)$ fuel blends are higher than pure gasoline fuel $(0.282 \%)$. The obvious explanation suggest that the hydroxyl and oxygen molecules present in the ethanol further oxygenated the blended fuel samples, and improves their air-fuel ratio and enhanced the combustion performance of the fuel samples under low loading conditions. Under higher loading condition, the change of state - i.e. from molecular oxygen to atomic oxygen is likely to explain the decrease in BTE [22].

The BTE of GE2, GE4, GE6 and GE8 fuel samples are higher than that of gasoline especially for 1000g load, while the BTE of GE10 are less than that of gasoline at $500 \mathrm{~g}$. The lower brake thermal efficiency obtained could be attributed to reduction in calorific value and their low heat input requirement for higher power output at a given load. It was also observed that the proportion of ethanol in the blends somewhat increases with the decrease in thermal efficiency. Hence, the decrease in brake thermal efficiency with increase in blend concentration could be ascribed to the poor atomization of the fuel blends due to their higher fuel viscosities [22].

Furthermore, the rapid fall in brake thermal efficiencies and power output of all tested oil, revealed that; specific fuel consumption relates conversely with thermal efficiency. This however emphasizes the desirability of running engines at or near their maximum power output to expect good return for the burnt fuel. It was also reported that the principal causes of the falling-off in thermal efficiency as the power output reduces could be explained in terms of; increase in mechanical losses in engines relative to useful power output, increase in throttling losses associated with the carburetor in small engines and deterioration in combustion efficiency [25].

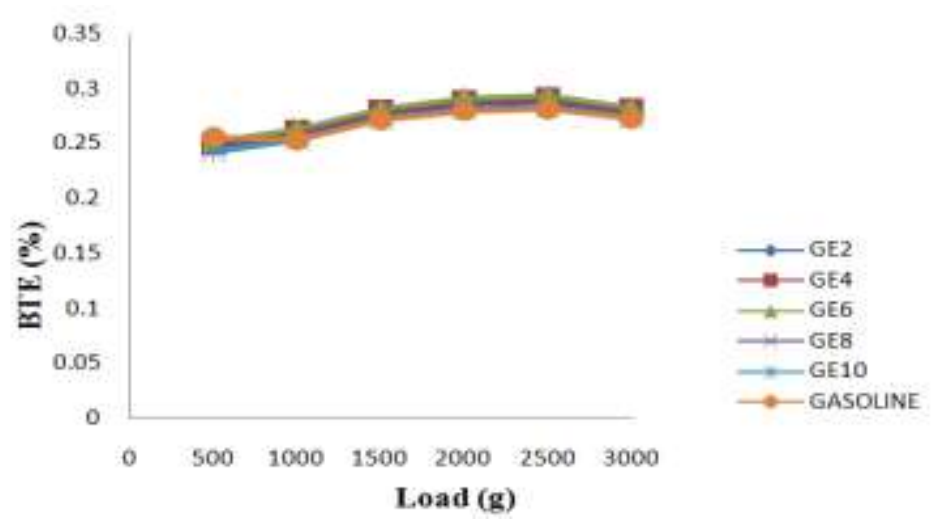

Figure 5. Variation of BTE versus engine loads for tested fuel samples. 


\subsection{Effect of fuel samples on brake specific energy consumption.}

The inverse of thermal efficiency is often referred to as brake specific energy consumption (BSEC). BSEC is the energy input required to develop unit brake power and is independent of the fuel used. When two different fuels of different heating values are blended together, the fuel consumption may not be reliable, since the heating value and density of the two fuels are different. In such cases, the brake specific energy consumption (BSEC) will give more reliable value [26]. Fig. 6 shows the variation of BSEC for all tested samples with load. A decrease in BSEC with increase in load was observed up to a load level of about $2500 \mathrm{~g}$, and thereafter, a slight increase was observed. This could be explained in terms of the lower percent increase in fuel required to operate the engine compared to that of the brake power. The initial decrease in BSEC may be attributed to the complete and high combustion of fuel. Above the engine load level of $2500 \mathrm{~g}$, the time for complete fuel combustion decrease somewhat with a slight increase in BSEC. The increase ethanol proportion in the blend lowers the calorific value, increases the specific fuel consumption, and consequently explains the drop in BSEC of GE2(2.717\%), GE4(3.37\%), GE6(3.99\%), GE8(2.099\%), GE10(0.44\%) fuel samples than for gasoline fuel. The availability of the oxygen in the ethanol-gasoline fuel blend and higher mass flow of fuel entering into the engine could also be responsible for the lower BSEC in ethanol-gasoline blended fuel samples. It could also be seen from Table 2 that the higher viscosity of the blends due to increasing volumetric concentration of ethanol, tend to inhibit proper atomization of the blended fuel samples, and adversely affect fuel combustion [26].

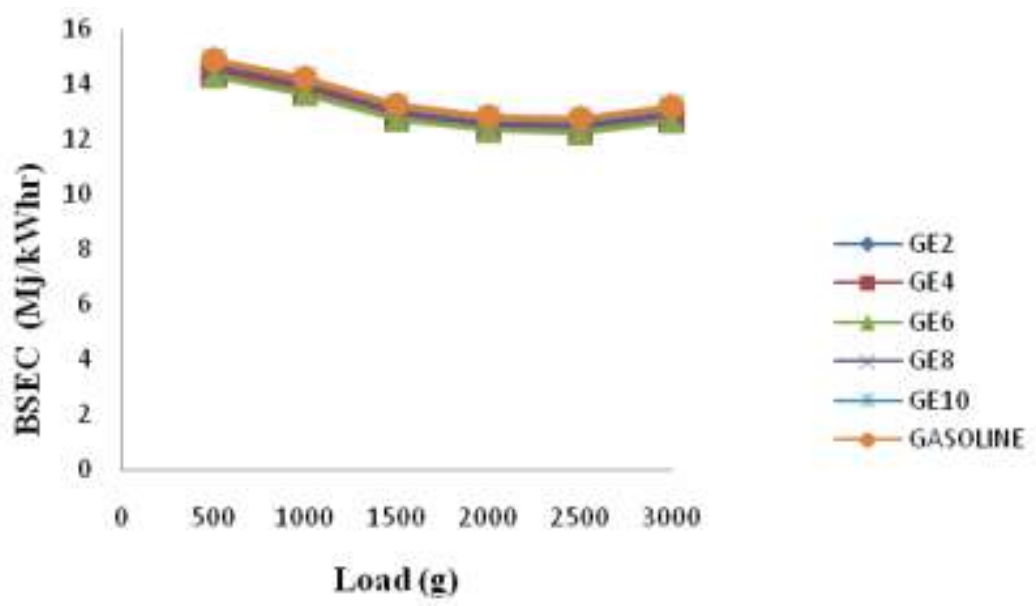

Figure 6. Variation of BSEC versus engine loads for tested fuel samples.

\section{CONCLUSION.}

From the foregoing study, the following could be concluded:

i. The density, specific gravity, kinematic viscosity, pour and cloud point, and octane number of gasoline is comparatively lower than that of ethanol extracted from Cadaba farinose forskk shrub. Conversely, the flash point, calorific value, and heat of combustion of gasoline are higher than their ethanol counterpart respectively.

ii. The density, specific gravity, kinematic viscosities, flash point, pour and cloud points of blended fuel samples somewhat increases with the increase in volumetric concentration of Cadaba farinose forsk $k$ ethanol in the fuel samples.

iii. The octane number, calorific value and heat of combustion of blended fuel samples decrease with the rise in concentration of ethanol in the blends.

iv. The higher torque, brake power, brake thermal efficiency, and lower BSEC values for GE2, GE4, and GE6 dual fuel mixtures over gasoline could be explained in terms of their higher octane number of ethanol, the presence of more unbounded oxygen molecules in the ethanol to support fuel combustion, and the higher calorific value of gasoline and that of the dual fuel mixtures, and better fuel atomization due to the comparatively lower viscosities and densities of the dual fuel mixtures.

v. Gasoline-Cadaba farinosa forssk ethanol blended fuel samples performed satisfactorily on spark-ignition engines without any engine hardware modification.

vi. A comparable engine performance behavior was observed for GE2, GE4 and GE6 blended fuel samples to gasoline fuel, and this further lends credence to the candidacy of ethanol derived from Cadaba farinosa forssk shrub as fuel -or fuel extender-for spark ignition engines. 


\section{ACKNOWLEDGEMENTS.}

The present work was supported by the Abubakar Tafawa Balewa University, Bauchi at the Department of Mechanical/Production Engineering, and the Federal Polytechnic, Bauchi Hence, the authors are grateful to the Management of the institutions for allowing the use of their laboratory facilities.

\section{REFERENCES:}

[1]. L.A. Martinelli, and S. Filoso. Expansion of Sugarcane Ethanol Production in Brazil: Environmental and Social Challenges, Ecol. Appl. 18, 2008, 885-898.

[2]. A.B.Hossain, M. S, Ahmed, S. A, Alshammari, M. A, Adnan, A. M. F, Annuar, M. S. M, Mustafa, H. Norah. Bioethanol fuel production from rotten banana as an environmental waste management and sustainable energy, Afr. J. Microbiol. Res. 5, 2011, 586-598.

[3]. J. Gao, D. Jiang, and Z. Huang.. Spray properties of alternative fuels: A comparative analysis of ethanol-gasoline blends and gasoline. Journal of Fuel. 86(2007)1645-1650.

[4]. S. Parag and V.Raghavan. Experimental investigation of burning rates of pure ethanol and ethanol blended fuels. Combustion and Flame, 156(5) 2009, 997-1005

[5]. E10: Every vehicle's ethanol blend. http:// www.driveingethanol.org Archived May 12, 2008. Retrieved 14/09/2015

[6]. H.S. Yu“cesu, A. Sozen, T.,Topgu, and E. Arcakliog. Comparative study of mathematical and experimental analysis of spark ignition engine performance used ethanol-gasoline blend fuel. Journal of Applied Thermal Engineering. 27, 2007, $358-368$.

[7]. "Towards Sustainable Production and Use of Resources: Assessing Biofuels" (PDF). Report of United Nations Environment Programme See Table 3.3. 2009-10-16. Archived from the original (PDF) on 2009-11-22. Retrieved 2009-10

[8]. D. Greg, and J. Saddler, J. Biomass Bioenergy. 9, 1995, 287-302

[9]. B.A. Gambo, R.I. Ejilah, and K. Dahuwa. Fuel property characterization of ethanol derived from Cadaba farinosa forssk shrub. Journal of Nigerian Institution of Mechanical Engineers, 6 (1),2016,92-98.

[10]. R. Amber. A. Studies on the Chemical Constituents of Cadaba farinosa, PhD thesis. University of Karachi, Pakistan. 1990:1-147

[11]. D.L. Nelson and M.M. Cox. Lehninger Principles of Biochemistry, $3^{\text {rd }}$ Ed., (Cranbury, NJ: USA Worth Publishing, 2000).

[12]. ASTM Standard parts 17 and 18, American Society for Testing and Materials, Philadelphia, Pennsylvania.1991

[13]. SAE practice SAE J1312 procedure for four stroke compression and spark ignition engines SAE Handbook, Society of Automotive Engineers, (Warrendale, Pennsylvania: SAE Publications, 1995)

[14]. TD110-TD115 Test Bed and Instrumentation Manual for Small Engines, (London: TQ Educational and Training Publishers, 2000).

[15]. B.M. Masum, H.H. Masjuki,M.A. Kalam, S.M.Palash, and M. Habibullah. Effect of alcohol-gasoline blends optimization on fuel properties, performance and emissions of a SI engine. Journal of Cleaner Production, 86, 2015, 230-237

[16]. Chemical and Physical Characteristics of Ethanol and Hydrocarbon Fuels, Module Two. A publication of Ethanol Emergency Response Coalition. http://ethanolrfa.3cdn.net/46092913d3aa01b12f_hcm6i6j6j.pdf, 2003. Retrieved on 15/ 10/2016

[17]. W.N. Maawa, R. Mamat, G. Najafi, O. Majeed Ali, and A. Aziz, A Engine performance and emission of compression ignition engine fuelled with emulsified biodiesel-water. 3rd International Conference of Mechanical Engineering Research (ICMER 2015) IOP Publishing IOP Conf. Series: Materials Science and Engineering 100 (2015) 012061 doi:10.1088/1757-899X/100/1/012061

[18]. M.H.M. Yusoff, A.Z. Abdullah, S. Sultana, and M. Ahmad. Energy Policy 62 , 2013, 456-62

[19]. C.Y. Lin and K.H. Wang. Fuel 83, 2004, 507-15

[20]. H. Aydin and H. Bayindir. Performance and emission analysis of cottonseed oil methyl ester in a diesel engine, Renewable Energy.35, 2010, 588-592.

[21]. B.A. Gambo. Performance Characteristics of Gasoline -Cardaba farinose forskk ethanol blends in Spark Ignition. M.Eng thesis. Abubakar Tafawa Balewa University, Bauchi-Nigeria, 201, 33.

[22]. A.K. Agarwal. Biofuels (alcohols and biodiesel) applications as fuels for internal combustion engines, Prog. Energy Combustion Science. 33,2007,233-271.

[23]. J. Grabys. Influence of composition of gasoline-ethanol blend parameters of internal combustion engines, Journal of Kones, Internal Combustion Engines. 10, 2012, 3-4.

[24]. H.H. Masjuki and M.A.Maleque. Wear performance and emission of a two- stroke engine running on palm oil methyl ester blended lubricant. IMechE Journal of Engineering Tribology. Proc. Part J. 210 (J4), 1996, 213-219

[25]. Plint and Partners (1984): Shell- Plint Engine Test Bed Manual. (England: Plint and Partners Publications, 1984).

[26]. S. Bajpai and L.M. Das. Feasibility of utilization of Fatty Acid Ethyl Esters-Diesel blends as an act to fatty acid methyl esters-Diesel blend, Proceedings of the 7th International Conference of Biofuels organized by Winrock international. 2010, 91-100.

\section{Biographies}

Buhari Abubakar Gambo, Assistant Lecturer and $\mathrm{PhD}$ research student in the Department of Mechanical/Production Engineering, Abubakar Tafawa Balewa University, Bauchi- Nigeria. He is a Registered Engineer with the Council for the Regulation of Engineering in Nigeria (COREN). His area of research interest include; fuel and internal combustion systems, renewable energy and bioenergy research.

Tel: +2348032493110; E-mail: gmbuhari@yahoo.com

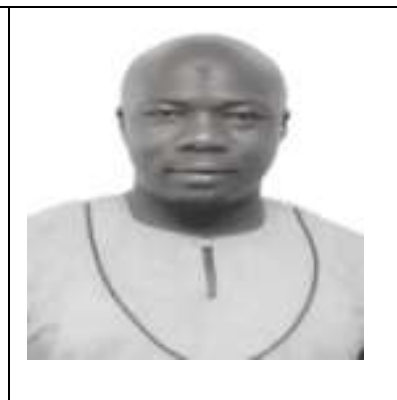


Robinson Ichakpa Ejilah, PhD, is a Senior Lecturer in the Department of Mechanical/Production Engineering, Abubakar Tafawa Balewa University, Bauchi-Nigeria, Former Chief Lecturer and Head of Mechanical Engineering Department, Federal Polytechnic, Bauchi. He is at present a Fellow and Deputy National Chairman, of the Nigerian Institution of Mechanical Engineers (NIMechE). He is also a corporate member of Nigerian Society of Engineers (NSE), Solar Energy Society of Nigeria (SESN), and League of Researchers in Nigeria (LRN). Dr. Ejilah is a Registered Engineer with the Council for the Regulation of Engineering in Nigeria (COREN). He has a penchant for fuel and combustion processes, internal combustion engines, bioenergy, renewable fuels and bio-lubricants research

Tel: +2348057243194; E-mail: irejilah@atbu.edu.ng; rejilah@gmail.com.

Kamal Dahuwa, is a Research Fellow I, with the National Center for Petroleum Research and Development, Abubakar Tafawa Balewa University Bauchi Nigeria. He is also a $\mathrm{PhD}$ research student in the Department of Mechanical /Production Engineering, Abubakar Tafawa Balewa University, Bauchi. He is a corporate member of the Nigerian Institution of Mechanical Engineers (NIMechE), and corporate member of the Nigerian Society of Engineers (NSE), and aRegistered Engineer with the Council for the Regulation of Engineering in Nigeria (COREN). His area of research interest is on fuel and internal combustion systems, renewable energy and bioenergy research.

Tel: +2348061555029; E-mail: kmldahuwa@gmail.com 